\title{
Onderzoeksnotitie: Strategische samenwerking tussen uitzenders en inleners. Op zoek naar de balans tussen flexibiliteit en zekerheid
}

\author{
Anneke Goudswaard, Tony Brugman en Jan de Leede*
}

\begin{abstract}
Strategische samenwerking tussen inlenende organisaties en uitzendorganisaties is niet vanzelfsprekend. Veelal komt de relatie terecht in een tariefdiscussie, waarbij flexibele arbeid geleverd moet worden tegen het laagste tarief. Toch zijn er ook voorbeelden van meer strategische relaties tussen inleners en uitzenders. Deze onderzoeksnotitie beschrijft drie typen samenwerkingsverbanden: (I) gericht op efficiëntie en kostenbesparingen, (2) gericht op flexibiliteit op korte en lange termijn en (3) gericht op arbeidsmarkt en scholing. De succesfactoren voor deze strategische samenwerkingsverbanden zijn een gevoelde noodzaak tot verandering en breed draagvlak, een gedeelde visie op HRM met aandacht voor vast én flexibel personeel en professionele bedrijfsprocessen bij alle partners. Onder deze condities kan een strategische samenwerking zowel positief zijn voor de organisatie als voor (flexibele) werknemer.
\end{abstract}

Trefwoorden: uitzendarbeid, uitzendbranche, flexibiliteit, human resources management

\section{Inleiding}

Organisaties zijn continu onderhevig aan veranderingen vanuit hun omgeving. Om hun concurrentiepositie te verstevigen zoeken organisaties naar middelen om op deze dynamiek te anticiperen. Ze kunnen daarbij gebruikmaken van de flexibiliteit van personeel, proces en organisatie (De Leede \& Goudswaard, 2008; De Leede et al., 2002). Uit onderzoek komt naar voren dat bedrijven een groot beroep doen op de flexibiliteit van hun personeel (Goudswaard \& Davidse, 2006, 2007; Goudswaard et al., 2007). Daarbij wordt veel flexibiliteit gevraagd van het vaste personeel (flexibele houding, flexibele werktijden, brede inzetbaarheid), maar worden ook allerlei flexibele contracten ingezet. De verwachting is dat het aandeel van flexibele contracten (de flexibele schil) in organisaties de komende jaren zal toenemen (Goudswaard et al., 2007).

Een specifieke vorm van flexibele arbeid betreft uitzendarbeid. Het specifieke aan dit type arbeid is de driehoeksrelatie tussen de uitzendkracht, het uitzendbureau en de inlenende organisatie. Nederland neemt, met een penetratiegraad van 2,5\%, binnen Europa de tweede plaats in als het gaat om de omvang van uitzendarbeid (Eurociett, 2007). Data van de European Working Conditions Survey laten zien dat uitzendkrachten over het algemeen tot de lagere inkomensgroepen behoren en slechts beperkt training ontvangen (Pederson, Hansen \& Mahler, 2007; Storrie, 2002). In Nederland zien we dat het gemiddelde opleidingsniveau van uitzendkrachten gestaag toeneemt (Donker van Heel et al., 2007).

* Anneke Goudswaard is werkzaam bij TNO Kwaliteit van Leven, Business Unit Arbeid, Postbus 718, 2130 AS Hoofddorp. E-mail: anneke.goudswaard@tno.nl.

Tony Brugman is werkzaam bij TNO Kwaliteit van Leven, Business Unit Arbeid.

Jan de Leede was gedurende het onderzoek werkzaam bij TNO, maar werkt sinds 1 november 2008 bij ModernWorkx. Hij is tevens verbonden aan de Universiteit Twente. 
Hoewel het gros van uitzendarbeid nog steeds gericht is op het opvangen van piek en ziek, zien we een toegenomen diversiteit in de dienstverlening van de uitzendbranche aan bedrijven. Bedrijven zijn niet alleen op zoek naar snel inzetbaar en kwalitatief goed flexibel personeel, maar hechten ook waarde aan een professionele en meedenkende uitzendorganisatie (Goudswaard et al., 2007). Een goede samenwerking tussen uitzendorganisaties en inleners is echter niet vanzelfsprekend. Ten eerste klagen uitzendbureaus over het feit dat zij keer op keer in een tariefdiscussie terechtkomen met hun klanten; een opgebouwde relatie kan zo weer tenietgedaan worden bij een nieuwe aanbesteding. Inleners hebben dienstverlening voor de laagste prijs als eerste prioriteit. Ten tweede zijn inleners op hun beurt niet tevreden over de geleverde prestaties van de uitzendorganisaties. Het weerwoord van de uitzendorganisaties is dan dat men niet voor het laagste tarief had moeten gaan en samen moet investeren in een langeretermijnrelatie. Een mogelijkheid om uit dit dilemma te komen is wellicht een meer strategische samenwerking tussen inleners en uitzendorganisaties.

Hier liggen wel enkele belangrijke onderzoeksvragen: is het mogelijk om meer strategisch en over langere termijn met elkaar samen te werken? En wie van de betrokkenen profiteert daarvan: de uitzendorganisatie, de inlenende organisatie en/of de flexibele werknemers?

Onze hypothese is dat een strategische samenwerking tot een meer duurzame relatie tussen inlener en uitzender leidt, waarbij het mogelijk is om een betere match te realiseren met de behoeften van de inlener en tegelijkertijd een betere match met de behoeften van de flexibele werknemer. In een exploratief onderzoek hebben we deze veronderstelling getoetst. Daarvoor hebben we uitzendorganisaties gevraagd om samenwerkingsverbanden aan te leveren die zij als strategisch en succesvol ervaren. Deze cases hebben we onderzocht op onze hypothese. Daarnaast hebben we onderzocht wat succesfactoren zijn voor dit type samenwerkingsverbanden. Kennis van de succesfactoren biedt immers de mogelijkheid om boven het zojuist beschreven dilemma uit te komen.

In deze onderzoeksnotitie doen we verslag van dit exploratieve onderzoek. We lichten eerst de vraagstelling en onderzoeksmethode toe. Bij de resultaten bespreken we de aard van de samenwerkingsverbanden. Dit geeft zicht op de aanleiding voor de samenwerking en het duurzame karakter van het samenwerkingsverband. Vervolgens bespreken we de mogelijke opbrengsten voor de inlener en de werknemers. Ten slotte gaan we in op de vraag welke factoren bijdragen aan een succesvolle samenwerking.

\section{Onderzoeksvraag en -methode}

De centrale vraag van ons onderzoek luidde: is in de onderzochte cases inderdaad sprake van een strategische samenwerking met een duurzaam karakter? En zo ja, leidt dit type samenwerking dan tot betere resultaten voor de inlener, en tevens meer zekerheid en betere ontwikkelkansen voor de betrokken werknemers? Een nevenvraag betreft: wat zijn succesfactoren voor strategische samenwerking?

Voor ons onderzoek hebben we samenwerkingsverbanden tussen uitzenders ${ }^{1}$ en inleners onderzocht (zie ook Goudswaard et al., 2007). Verschillende uitzenders zijn benaderd met de vraag of zij cases konden aanleveren waarbij in hun ogen sprake was van een 
succesvolle en strategische samenwerking. In alle cases zijn interviews gehouden met contactpersonen van de inlener (directeur, HR-manager, operationeel manager en/of inkoper) en contactpersonen van de uitzender (accountmanager en/of in house medewerker). We hebben gesproken met diegenen die verantwoordelijk waren voor het tot stand komen van de samenwerkingsovereenkomst, maar ook met diegenen die verantwoordelijk zijn voor de uitvoering in de dagelijkse praktijk. Voor zover mogelijk hebben we ook informatie opgevraagd over bedrijfsprestaties en personeelsgegevens (verzuim, verloop). We hebben vragen gesteld over de aanleiding tot de samenwerking, maar ook over de opbrengsten voor inlener en werknemer. Daarbij is de situatie vóór de samenwerking vergeleken met de nieuwe situatie. Deze cases vormen een eerste verkennende fase in een langer lopend onderzoek. In dit stadium hebben we geen werknemers gesproken en ook niet zelf kwantitatieve of longitudinale gegevens verzameld om de resultaten te onderbouwen. We beschrijven hier dus vooral visies van de betrokken managers, die gedeeltelijk zijn gebaseerd op cijfers uit het bedrijf.

We bespreken negen cases, aangeleverd door in totaal acht uitzend- en detacheringsorganisaties. Deze negen cases beslaan verschillende sectoren, namelijk de voedingsmiddelenindustrie, de energiesector, de logistieke sector, de luchtvaartsector, de overheid, de technische sector, de financiële en de zakelijke dienstverlening (zie tabel 1).

\section{Tabel I Overzicht van de onderzochte cases}

\begin{tabular}{|c|c|c|c|}
\hline $\begin{array}{l}\text { Case- } \\
\text { nummer }\end{array}$ & Aanleiding & Sector & Samenwerkingsvorm \\
\hline 1 & $\begin{array}{l}\text { Inefficiënte inzet van (flexibel) } \\
\text { personeel, noodzaak tot } \\
\text { kostenbesparing }\end{array}$ & $\begin{array}{l}\text { Voedingsmiddelenindustrie: } \\
\text { productiepersoneel }\end{array}$ & $\begin{array}{l}\text { Uitzendorganisatie in huis, } \\
\text { verantwoordelijk voor personele } \\
\text { planning }\end{array}$ \\
\hline 2 & $\begin{array}{l}\text { Traag en inefficiënt wervings- en } \\
\text { selectieproces }\end{array}$ & $\begin{array}{l}\text { Voedingsmiddelenindustrie: } \\
\text { totale personeel }\end{array}$ & $\begin{array}{l}\text { Uitbesteding van werving en } \\
\text { selectie aan uitzendorganisatie }\end{array}$ \\
\hline 3 & $\begin{array}{l}\text { Mismatch in inzet van flexibel } \\
\text { personeel, hoog verloop }\end{array}$ & Energie: callcentermedewerkers & $\begin{array}{l}\text { Uitzendorganisatie in huis, geza- } \\
\text { menlijke verbetering inleen- } \\
\text { proces en operationele planning }\end{array}$ \\
\hline 4 & $\begin{array}{l}\text { Traag en inefficiënt outplace- } \\
\text { menttraject, boventallig perso- } \\
\text { neel }\end{array}$ & $\begin{array}{l}\text { Financiële dienstverlening: totale } \\
\text { personeel }\end{array}$ & $\begin{array}{l}\text { Samenwerking met een zeer } \\
\text { groot aantal partners, onder- } \\
\text { steund door diverse ICT- } \\
\text { systemen (interne en externe } \\
\text { arbeidsmarkt) }\end{array}$ \\
\hline 5 & $\begin{array}{l}\text { Vergroten van flexibiliteit binnen } \\
\text { de hele organisatie, meer planma- } \\
\text { tige aanpak van personele inzet }\end{array}$ & $\begin{array}{l}\text { Zakelijke dienstverlening: totale } \\
\text { personeel }\end{array}$ & $\begin{array}{l}\text { Uitzender in huis, gezamenlijke } \\
\text { verbetering van HR-processen } \\
\text { en personele flexibiliteit }\end{array}$ \\
\hline 6 & $\begin{array}{l}\text { Aandacht bedrijf op kerntaak } \\
\text { (logistiek) en overdracht zorg } \\
\text { voor personeel aan partner }\end{array}$ & Logistiek: productiepersoneel & $\begin{array}{l}\text { Joint venture tussen logistiek } \\
\text { bedrijf en uitzendorgansiatie, } \\
\text { waarbij deze verantwoordelijk is } \\
\text { voor HR-taak en operationele } \\
\text { planning }\end{array}$ \\
\hline 7 & $\begin{array}{l}\text { Grillig werkaanbod, onvoorspel- } \\
\text { bare toekomst }\end{array}$ & Luchtvaart: technisch personeel & $\begin{array}{l}\text { Detacheringsorganisatie levert } \\
\text { personeel aan bedrijf (flex-unit) }\end{array}$ \\
\hline 8 & $\begin{array}{l}\text { Schaarste op arbeidsmarkt, } \\
\text { imago gemeente }\end{array}$ & Overheid: technisch personeel & $\begin{array}{l}\text { Traineeship opgezet door } \\
\text { gemeente (werk), ingenieursbu- } \\
\text { reau (mentor) en detacheringsor- } \\
\text { ganisatie (werkgeversrol) }\end{array}$ \\
\hline 9 & $\begin{array}{l}\text { Schaarste aan vakbekwaam } \\
\text { personeel, competentieontwik- } \\
\text { keling }\end{array}$ & Techniek: technisch personeel & $\begin{array}{l}\text { Detacheringsorganisatie organi- } \\
\text { seert samen met verschillende } \\
\text { inleners specifieke opleidingen } \\
\text { aan ROC }\end{array}$ \\
\hline
\end{tabular}




\section{Onderzoeksresultaten}

\section{De aard van de strategische relatie: verschillende aanleidingen}

Op grond van de interviews concluderen we dat er in de onderzochte cases inderdaad sprake lijkt van een strategische relatie, waar beide partijen (uitzender en inlener) belang hebben om deze relatie tot een succes te maken en gedurende langere tijd voort te zetten.

In de meeste cases zien we bij de inlener een behoefte om de personele inzet structureel te verbeteren, het HR-beleid (werving, selectie, retentie, doorstroom, uitstroom) meer samenhangend vorm te geven en daarin zowel vaste als flexibele werknemers te betrekken. Alle organisaties zijn zich bewust van het feit dat een grotere flexibiliteit voor het inlenende bedrijf van groot belang is en dat de flexibele werknemers hierbij een belangrijke rol spelen. Een andere overeenkomst tussen de cases is de behoefte om de samenwerking met partners te versterken. Bij een meer structurele aanpak van de flexibele inzet van personeel past ook een meer duurzame samenwerkingsrelatie met partners.

Verschillen zijn er ook (zie tabel 2). Zo kunnen we, uitgaande van de aanleiding tot de samenwerking, grofweg drie typen samenwerkingsverbanden onderscheiden. In het eerste type (cases $1 \mathrm{t} / \mathrm{m} 4$ ) ligt de focus op efficiencyverbetering. Het tweede type samenwerkingsverband (cases $5 \mathrm{t} / \mathrm{m}$ ) heeft de focus op het vergroten van de flexibiliteit van het inlenende bedrijf. In het laatste type (cases 8 en 9) staan arbeidsmarkt en opleiding centraal.

Tabel 2 Overzicht van de verschillende typen aanleidingen en de aard van het samenwerkingsverband

\begin{tabular}{lll}
\hline Casetype & Aanleiding/behoefte & Aard van het samenwerkingsverband \\
\hline I & Inefficiënte planning van personeel & In house-constructie \\
Inefficiënt wervings- en selectieproces & Structurele inzet van uitzendkrachten \\
Mismatch vraag en aanbod uitzendkrachten & Uitbesteding personeelsproces (werving, selectie en \\
Hoog verloop & planning) \\
Boventalligheid van personeel & On site recruiter \\
Continuitteit bedrijf in gevaar & Nieuwe HR-diensten (aanpassen functieprofielen, \\
Noodzaak tot kostenbesparing & competentiemanagement, training, arbeidsmarktplaats, \\
& retentieplan) \\
& Organisatie van interne en externe marktplaats \\
& Focus op kernactiviteiten (kunnen groeien & Strategische samenwerking (bijv. joint venture) \\
in de markt) & Uitbesteding ontwikkeling en beheer van personeels- \\
Kostenbesparing & Pool \\
Grillig patroon werkanbod & Uitbesteding capaciteitenmanagement en arbeidsmarkt- \\
Onvoldoende flexibiliteit vast personeel & en werkaanbodanalyse \\
& Structurele inzet van uitzendkrachten en gedeta- \\
& cheerden \\
& Scholingstraject voor flexkrachten \\
& Brede inzetbaarheid, locatieflexibiliteit \\
III $\quad$ Opzetten traineeships en opleidingen \\
Arbeidsmarktkrapte & Uitbesteding opleiding personeel \\
Ongewenst uitstroom ervaren personeel & Inzet van gedetacheerden \\
Slecht imago op de arbeidsmarkt & Delen van rol werkgeverschap, toezicht en coaching \\
Tekort aan beschikbare (maatwerk)oplei- & tussen meerdere organisaties \\
dingen &
\end{tabular}

Bij het eerste type samenwerkingsverband staat, zoals gezegd, efficiencyverbetering centraal. De noodzaak om kosten te besparen is in deze organisaties groot. Aanleiding om actie te ondernemen vormt onder meer een inefficiënte planning van personeel, te hoge inzet van flexkrachten, knelpunten in de werving en selectie en een te hoge uitstroom van flexkrachten. Dit zorgt onder meer voor te hoge personele kosten en 
gebrek aan continuïteit. Ook zien we in een van de cases een weinig efficiënt uitstroomtraject van boventallig personeel: er wordt op een te laat tijdstip mee begonnen, waardoor het traject traag verloopt en te duur is.

Om dit aan te pakken gaan de inleners een nauwe samenwerking aan met één of meerdere uitzenders. Bij deze samenwerking kan het gaan om het uitbesteden van het totale wervings- en selectieproces, om het overdragen van de verantwoordelijkheid van de personele planning aan de uitzender (zie het voorbeeld hierna), of om het opzetten van nieuwe HR-diensten (zoals een arbeidsmarktplaats, competentiemanagement en een retentieplan). De uitzender zit veelal 'in huis' bij de inlener.

Resultaten moeten snel worden bereikt. Daarbij wordt overigens na een eerste periode wel aan een meer duurzame constructie gewerkt.

Bij een bedrijf in de voedingsmiddelenindustrie wordt op een productielocatie de personele inzet onvoldoende efficiënt benut. Hierdoor loopt de continuïteit van het bedrijf gevaar. De noodzaak tot hogere efficiency en kostenbesparingen is groot. Om tot een slimmere inzet van het vaste én het uitzendpersoneel te komen, gaan de uitzender en de inlener samen aan de slag. Het gevolg is een aanpassing in de functieprofielen en in de planningsmethodiek. De uitzender zit 'in huis' en verzorgt de volledige personele planning, inclusief training en competentiemanagement. De inlener levert de productieplanning aan en de uitzender organiseert hier het vaste en uitzendpersoneel omheen. Afspraken zijn gemaakt op het volle terrein van de personele inzet (incl. individuele ontwikkeling). Door deze aanpassing worden de potentiële kwaliteiten van het personeel beter benut en is het personeel breder inzetbaar. Ook voor uitzendpersoneel is er sprake van taakverbreding, meer training en scholing. Het effect van een slimmere planning is een daling in het aantal ingeleende uren met meer dan $10 \%$ en een kostenreductie van $15 \%$.

Bij het tweede type samenwerkingsverbanden staat het vergroten van de flexibiliteit van de inlenende organisatie centraal. Een meer efficiënte inzet van personeel speelt ook hier een rol, maar men kijkt verder. In deze organisaties is de noodzaak om beter in te spelen op veranderingen in de markt groot. De organisaties willen groeien, maar hebben te maken met een grillig en onvoorspelbaar werkaanbodpatroon, met onvoldoende flexibiliteit bij het vaste personeel of maken zich zorgen over de toekomst van het bedrijf en de continuïteit van de werkgelegenheid als ze er niet in slagen om meer flexibel te opereren.

Ook hier gaat de inlener een strategisch samenwerkingsverband aan met een uitzender. Deze 'ontzorgen' de inlener door het overnemen van operationele en tactische personeelsprocessen (zowel beheer als capaciteitsplanning) of door het aanbieden van opgeleide flexibele werknemers. In dit type samenwerking is sprake van een langere opstartperiode en laten de resultaten wat langer op zich wachten. Beide organisaties hebben tijd nodig om hun eigen processen op orde te krijgen en om elkaar de juiste informatie te bieden (zie het voorbeeld hierna).

Een bedrijf dat zowel techniek als personeel levert voor reprodiensten, is op zoek naar manieren om de kosten te beperken en de flexibiliteit tussen de locaties te 
vergroten. Daarvoor is het contract met het vaste uitzendbureau uitgebreid tot een meer strategische relatie. De nieuwe afspraak houdt in dat de inlener en de uitzender structureel en projectmatig samenwerken aan het verbeteren van de processen en het vergroten van de flexibiliteit. Zo verzorgt de uitzender structureel werkaanbodanalyses en arbeidsmarktanalyses. De inlener moet op zijn beurt voor de locaties een betere jaarplanning realiseren. Een verbeterd automatiseringssysteem zorgt niet alleen voor een efficiënter inleen- en factureringsproces, maar biedt ook een goed overzicht van de flexibiliteitsbehoefte. Voor de flexibele werknemers is een retentieplan opgesteld (ontwikkeling, doorstroom). Ook is er een scholingstraject opgezet voor functies waar veel behoefte aan is. In het proces van inhuren van flexkrachten biedt dit de inlener een kostenbesparing en een grotere efficiency. De vacatures worden sneller en beter vervuld. Het werk op en tussen de locaties wordt beter gepland en men beschikt over adequatere en up-to-date managementinformatie over zowel werkaanbod als arbeidsmarkt. Voor het flexibele personeel betekent deze nieuwe manier van werken meer persoonlijke aandacht en loopbaanbegeleiding. Er is ook meer aandacht voor scholing. Het verzuim en verloop onder de flexkrachten is lager terwijl de verblijfsduur langer is.

Bij het derde type samenwerkingsverbanden staan, zoals gezegd, arbeidsmarkt en opleiding centraal. Men heeft te maken met arbeidsmarktkrapte, tekort aan vakbekwaam personeel, onvoldoende wervingskracht op de arbeidsmarkt, ongewenste uitstroom van ervaren personeel en onvoldoende op maat ontwikkelde opleidingen.

Om aan problemen het hoofd te bieden slaan meerdere inleners en uitzenders de handen ineen om gezamenlijk nieuwe mogelijkheden te scheppen voor het binden en opleiden van hun personeel. Dit gebeurt bijvoorbeeld door het opzetten van een traineeship (zie het voorbeeld hierna) of het opzetten van maatwerkopleidingen door het ROC. In dit type samenwerking is het niet altijd het inlenende bedrijf dat het initiatief neemt, maar kan het ook de uitzender zijn die partners bij elkaar zoekt. De rol van de uitzender is drieledig, als werkgever, toezichthouder en coach tussen de betrokken organisaties.

Een gemeente ondervindt een ongewenste uitstroom van ervaren personeel door de aantrekkingskracht van de profitsector. Er was een duidelijke behoefte aan instroom van nieuwe jonge civieltechnici. Om hierin te voorzien heeft de gemeente een samenwerking opgezet met twee partijen. Een detacheringsbureau selecteert trainees en begeleidt hen in hun persoonlijke ontwikkeling. Een ingenieursbureau levert een mentor voor vakinhoudelijke ontwikkeling. Deze mentor wordt weer gecoacht vanuit het detacheringbureau. De trainees werken in principe binnen de gemeente. Het voordeel van deze nieuwe manier van werken voor de gemeente is dat er nieuwe mensen worden binnengehaald. Door de ondersteuning van het ingenieursbureau brengen ze bovendien al direct kennis en nieuwe inzichten bij de gemeente binnen. Voor de trainees is deze manier van werken een goede opstap op de arbeidsmarkt en door de begeleiding vanuit drie partijen positief voor de persoonlijke ontwikkeling. 


\section{Gerapporteerde opbrengsten voor inlener en werknemers}

Op basis van de interviews komen we ook tot de voorlopige conclusie dat dit type samenwerkingsverbanden voordeel kan bieden voor zowel het inlenende bedrijf als de betrokken werknemers. Doordat de uitzender dichter op de processen van de inlener komt te zitten en over betere en meer vroegtijdige informatie beschikt, kan beter en sneller worden ingespeeld op de behoeften van het inlenende bedrijf. Doordat beide partijen samen én expliciet aandacht besteden aan een meer toekomstgericht HR-beleid, lijkt deze samenwerking ook tot goede resultaten voor de betrokken flexkrachten te leiden. Zo laten de personeelscijfers onder meer een lager verzuim en verloop zien onder flexibele werknemers. Gerapporteerd worden verder een meer persoonlijke coaching en loopbaanbegeleiding en een bredere inzetbaarheid, zaken die voor uitzendkrachten zeker geen vanzelfsprekendheid zijn.

Een focus op kostenbesparingen of op een grotere flexibiliteit van de organisatie gaat in deze voorbeelden wel degelijk samen met meer aandacht voor het personeel. Juist door personeel slimmer in te zetten worden ook voordelen voor het bedrijf behaald.

Sommige opbrengsten werden al op de korte termijn opgetekend (kostenbesparing, betere inzet van flexkrachten). Andere opbrengsten hebben meer tijd nodig om zichzelf te bewijzen (flexibiliteit bedrijf en personeel op langere termijn, continuïteit van de werkgelegenheid). In ons verkennende onderzoek hebben we deze opbrengsten nog beperkt kunnen onderbouwen. Diverse korte-termijnopbrengsten konden de bedrijven wel met cijfers onderbouwen. Vooral bij de langere-termijnopbrengsten is nog nader onderzoek nodig.

We zien wel verschillen tussen de typen in de aard van de opbrengst en de termijn waarop deze worden gerealiseerd (zie tabel 3).

In het eerste type samenwerkingsverband ligt de focus op korte-termijnresultaten, maar lijken ook langere-termijnopbrengsten behaald te kunnen worden. Op de korte termijn behalen deze organisaties snellere doorlooptijden van het inleenproces, een verhoging van het aantal plaatsingen en een verlaging van het aantal inleenuren. Hiermee worden de personele kosten gereduceerd. Op de middellange termijn zien de leidinggevenden al dat het flexibele personeel zich meer betrokken en gemotiveerd toont. Zo signaleert men een daling in ongewenste uitstroom en verzuim, of een verhoging van gewenste uitstroom. Voor de langere termijn verwachten de betrokkenen beter inzetbaar en plaatsbaar personeel, met een bredere inzetbaarheid binnen de eigen organisatie en een betere positie op de arbeidsmarkt.

In het tweede type samenwerkingsverband ligt de focus op de langere-termijnflexibiliteit. Ook hier worden echter ook op korte termijn al resultaten behaald, zoals een snellere en betere invulling van vacatures, een betere personele planning en een daling van de personele kosten. Men verwacht op de langere termijn nog grotere winst te behalen, namelijk een vergroting van de markt, een betere en meer flexibele inzet van het personeel en een lager (ongewenst) verloop. Bijkomende opbrengsten voor het bedrijf zijn meer inzicht in de eigen flexibiliteitsbehoefte (inzicht in de marktvraag en vertaling naar benodigde capaciteit), de mogelijkheid om sneller op de markt te reageren, hogere productiviteit en het behoud van vakmanschap en kwaliteit. 
Op korte termijn rapporteren de betrokkenen al positieve opbrengsten voor het personeel: in het bijzonder signaleren de leidinggevenden meer persoonlijke loopbaanbegeleiding en aandacht. Hiermee streven de partners na dat de werknemers (zowel vaste werknemer als flexkracht) meer werkinhoudelijke ontwikkelmogelijkheden worden geboden en meer inzicht in hun eigen mogelijkheden. Op de langere termijn moet dit de (flexibele) werknemers een sterkere positie op de arbeidsmarkt bieden en meer garantie op werk.

Tabel 3 Gerapporteerde opbrengsten voor de inlener en de werknemers

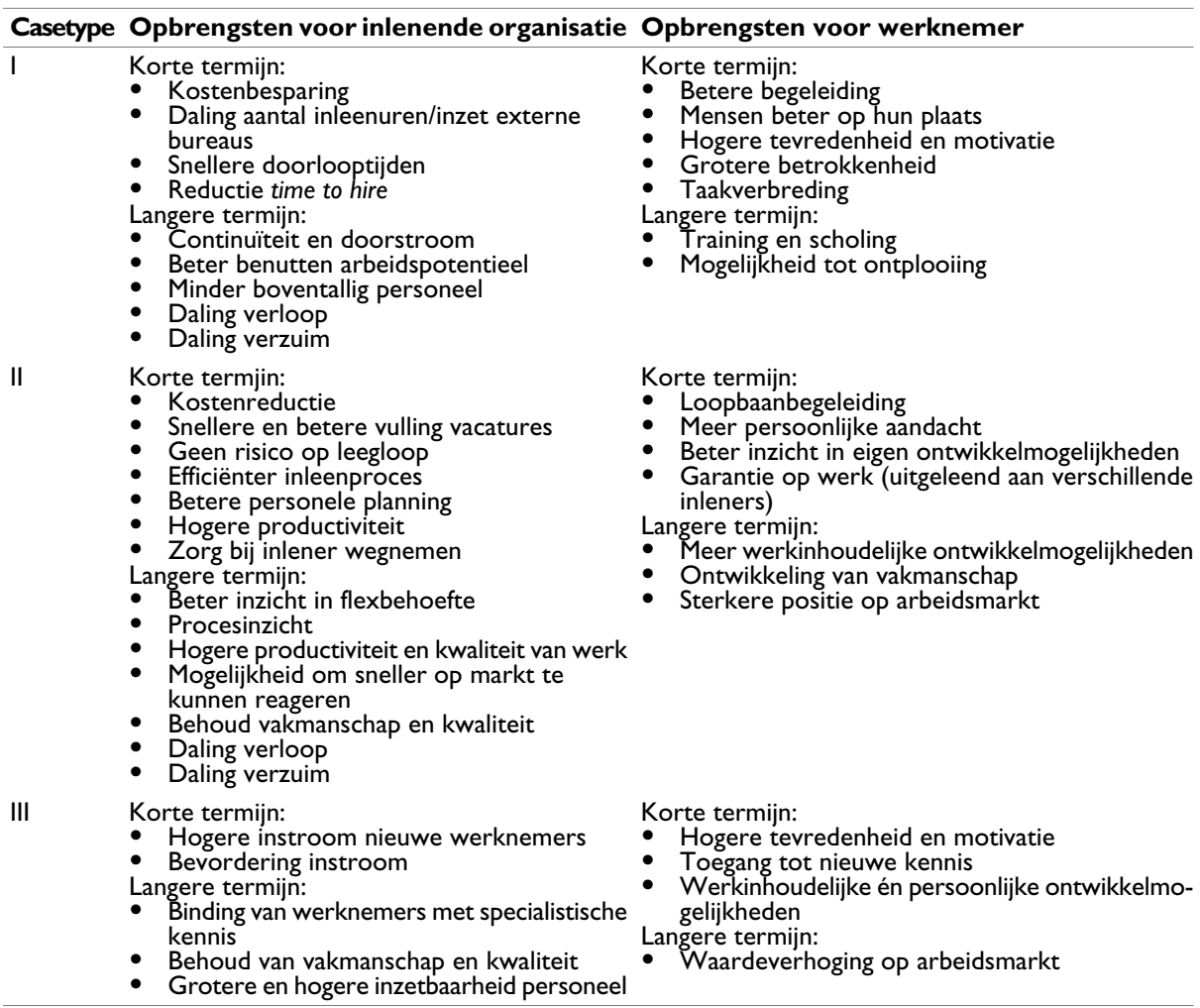

Aansluitend bij het doel van het derde type samenwerkingsverband hebben hier de voordelen vooral betrekking op de arbeidsmarkt. Bedrijven zien op korte termijn een hogere instroom van nieuwe werknemers en een lager verloop. Op langere termijn ondervinden of verwachten (afhankelijk van hoe lang de samenwerking al plaatsvindt) de bedrijven behoud van vakmanschap en kwaliteit. Voor werknemers wordt zowel vakinhoudelijke als persoonlijke training en coaching georganiseerd. Volgens leidinggevenden leidt dit tot een hogere motivatie en tevredenheid onder de werknemers. Men verwacht tevens dat het volgen van opleidingen de waarde van de werknemers op langere termijn op de arbeidsmarkt zal versterken. 


\section{Een eerste verkenning naar succesfactoren voor strategische samenwerking}

Een belangrijke vraag is nu welke condities van belang zijn voor een succesvolle samenwerking. In het kader van deze verkennende fase kunnen we deze factoren geen gewicht geven, we weten niet welke er doorslaggevend zijn. We kunnen ze wel benoemen. We zullen hier geen onderscheid maken tussen de verschillende typen cases, daarvoor lijken de genoemde succesfactoren te algemeen (zie tabel 4).

\section{Tabel 4 Succesfactoren voor strategische samenwerking}

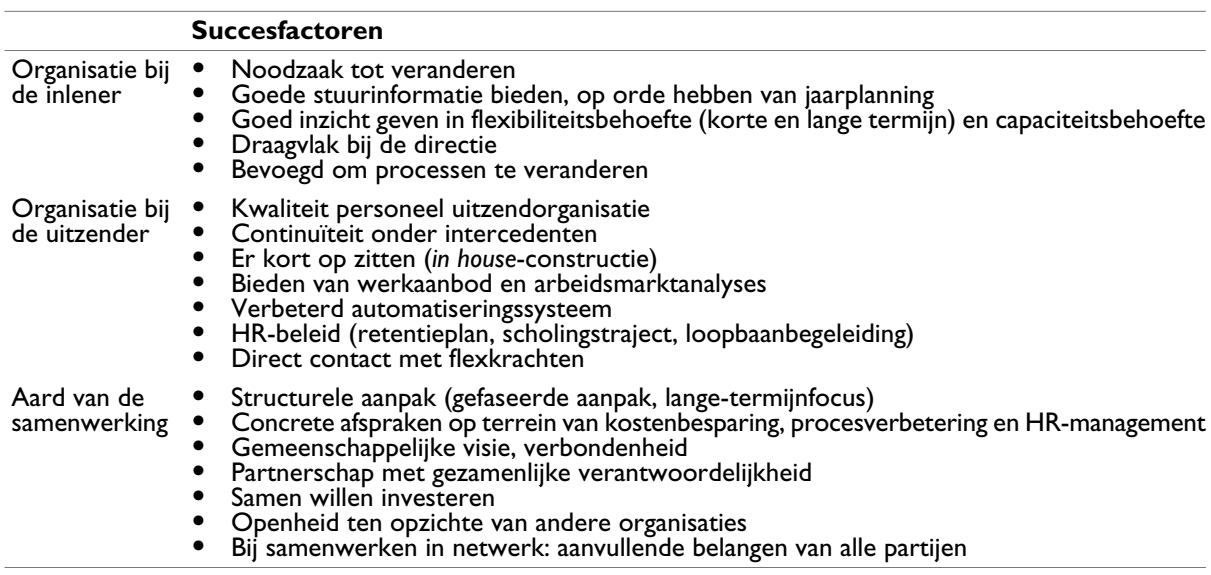

Een van de voornaamste succesfactoren is de noodzaak tot verandering: een nieuwe manier van werken wordt als noodzakelijk ervaren om te overleven. Daarbij is enerzijds draagulak op het niveau van de directie nodig. Anderzijds draagvlak op het niveau van de werkvloer en de bevoegdheid om de processen daadwerkelijk te veranderen. Een risico voor samenwerking is dat de noodzaak of het draagvlak kan veranderen: bijvoorbeeld de markt kan veranderen of er kan sprake zijn van reorganisaties en fusies, waardoor posities binnen het management opnieuw worden ingevuld. Zo kan het voorkomen dat een samenwerkingsverband wordt beëindigd, ondanks dat er al daadwerkelijk successen worden behaald. In dit type partnerschap blijft het spanningsveld bestaan tussen korte-termijnbeleid en het opbouwen van een duurzame relatie.

Een andere belangrijke succesfactor is een gezamenlijke en gedeelde visie op HR-beleid, waarbij het voor beide partijen vanzelfsprekend is dat niet alleen in het vaste personeel wordt geïnvesteerd, maar dat ook het flexibele personeel een essentieel onderdeel van het bedrijf vormt. Succesfactor voor de langere termijn is dat er concrete afspraken worden gemaakt zowel op het terrein van de efficiency van het inleenproces als op het brede terrein van HR-management (inclusief opleiding en loopbaanbegeleiding). Een risico bij de samenwerking is de langere adem die nodig is en de volledige breedte waarover de samenwerking moet worden geïmplementeerd. Het valt in deze situatie niet mee om alle neuzen één kant op te sturen en te houden: van de afdeling inkoop tot $\mathrm{HR}$, van de centrale directie tot de direct leidinggevenden. Men dient op alle niveaus voortdurend in gesprek te blijven. De samenwerking moet worden gezien als een gezamenlijke verantwoordelijkheid, waar alle partijen in wensen te investeren.

Een laatste factor voor het succes van de samenwerking is dat beide partijen hun eigen bedrijfsprocessen goed op orde moeten hebben. Zo moet de inlener onder meer goede 
informatie hebben én beschikbaar stellen over de werkprocessen en de marktvraag, vertaald in de capaciteitsbehoefte zowel in omvang als in competenties. Alleen dan kan de uitzender hier adequaat op inspelen. De uitzender moet onder meer goede informatie hebben én beschikbaar stellen over verzuim en verloop van personeel, over het potentiële aanbod op de arbeidsmarkt en moet een ondersteunend systeem bieden voor het aanvragen van vacatures of het indienen van urenbriefjes. Beide partijen dienen 'er kort op te zitten', voldoende betrokken te zijn bij de dagelijkse gang van zaken en open te staan voor kritiek.

\section{Conclusie en discussie}

De door ons beschreven cases laten zien dat uitzendorganisaties en inleners er in slagen om samenwerkingsverbanden aan te gaan die beantwoorden aan de flexibiliteitsbehoefte van de inlenende organisatie op korte en langere termijn en daarbij ook meer zekerheid en ontwikkelkansen lijken te bieden aan de betrokken werknemers. Tegelijkertijd zien we dat meer betrokken, beter inzetbaar personeel tot hogere efficiency en kostenbesparing voor de organisatie kan leiden.

De voorbeelden laten ook zien dat het behalen van een balans tussen organisatie en flexibele werknemers niet alleen voorbehouden lijkt aan 'high potentials', verbonden aan specialistische detacheringsbureaus. Ook productiemedewerkers of call-centermedewerkers met een uitzendcontract lijken te profiteren van een meer structurele visie van inleners en uitzenders op capaciteits- en competentiemanagement.

Nodig om meer onderbouwde uitspraken te doen met betrekking tot de duurzaamheid van de relatie en de balans tussen de belangen van de organisatie en de werknemers op langere termijn is longitudinaal onderzoek. Ook onderzoek op het niveau van de werknemers is noodzakelijk om te kunnen vaststellen in hoeverre dit type samenwerking voor hen inderdaad een structurele verbetering teweegbrengt.

Uit onderzoek blijkt dat een dergelijke samenwerking nog zeker niet de state of the art is (Goudswaard et al., 2007). Uit de cases blijkt dat het ook niet eenvoudig is om een dergelijke samenwerking tot stand te brengen en over langere periode vast te houden. Vervolgonderzoek moet uitwijzen wat nu werkelijk cruciale succesfactoren zijn om dergelijke samenwerking een duurzaam karakter te geven en welke maatregelen nodig zijn om de balans te versterken.

Tot slot een opmerking over de visie op flexibele contracten. Waar dit type flexibiliteit vaak gezien wordt als sluitpost of als middel om risico's af te dekken, is het beter om dit te beschouwen als een strategisch en essentieel onderdeel van de organisatie. Dit betekent dat men ook dit deel van de organisatie slim moet organiseren en managen en dat men ook de flexibele werknemers in het HR-beleid betrekt. Organisaties kunnen dit zelf doen, maar kunnen hiervoor ook partnerschappen aangaan met derden, waaronder uitzendorganisaties. Een voordeel van dergelijke partnerschappen is dat de ontwikkelmogelijkheden van personeel zich in principe niet tot de grenzen van de organisatie hoeven te beperken. Zoals hiervoor aangegeven, moet een dergelijk partnerschap gebaseerd zijn op een lange-termijnvisie op flexibiliteit en HR-management en niet op - het nu nog gebruikelijke - inhuur van arbeidskrachten tegen de laagste prijs. 
Vooral deze behoefte tot inzet van flexibele contracten tegen de laagste kosten staat namelijk een werkelijke balans tussen organisatie en personeel in de weg.

\section{Noot}

1 In deze notitie spreken we steeds over uitzenders en inleners. In de praktijk gaat het daarbij om leveren van flexibel personeel door uitzend- of detacheringsorganisaties aan inlenende organisaties. Het kan hierbij gaan om uitzendkrachten volgens het uitzendbeding, maar ook om uitzendkrachten of gedetacheerden met een tijdelijk of vast contract bij de uitzend- of detachteringsorganisatie. Als we het in deze notitie over flexibele werknemers of flexkrachten hebben, dan gaat het over al deze groepen.

\section{Literatuur}

Donker van Heel, P., Nuland, E. van \& Ende, M. van der (2007). Instroom uitzendkrachten 2006. Rotterdam: Ecorys.

Eurociett (2007). More work opportunities for more people. Unlocking the private employment agency industry's contribution to a better functioning labour market. Brussel: Eurociett.

Eurociett/UNI-Europa (2008). Joint Declaration on the Directive on working conditions for temporary agency workers. Brussel: Eurociett/UNI-Europa.

Goudswaard, A., Kraan, K.O. \& Dhondt, S. (2000). Flexibiliteit in balans. Flexibilisering en de gevolgen voor de werkgever én werknemer. Hoofddorp: TNO Arbeid.

Goudswaard, A. (2002). New forms of contractual relationships and the implications for occupational safety and health. Bilbao: European Agency for Safety and Health at Work.

Goudswaard, A. \& Andries, F. (2002). Employment Status and Working Conditions. Dublin: European Foundation for the Improvement of Living and Working Conditions.

Goudswaard, A. (2003). Flexibele arbeid - duurzame arbeid? De stand van zaken na twintig jaar flexibilisering. Proefschrift ter verkrijging van de graad van doctor aan de Katholieke Universiteit Nijmegen. Hoofddorp: TNO Arbeid.

Goudswaard, A. (2004). Flexibiliteit in balans: ontwikkelingen in flexibele arbeid en de gevolgen voor organisaties en werknemers. In: F. Glastra, S. van der Haar, M. Lens \& P. Schedler. Losse koppelingen: over flexibilisering van arbeid, organisatie en leefwereld. Den Haag: Reed Business Information, 49-62.

Goudswaard. A. \& Davidse. W. (2006). Flexibiliteit en productiviteit zijn geen gescheiden werelden. Gids voor Personeelsmanagement, 85 (9), 38-42.

Goudswaard, A. \& Davidse, W. (2007). Beperkt rekbaar: Meer aandacht voor flexibiliteitswensen werknemers. Gids voor Personeelsmanagement, 86 (10), 40-44.

Goudswaard, A, Leede, J. de, Hooff, M. van, Brugman, T., Klein Hesselink, J., Leeuw, M. de, Rhijn, G. van \& Gruyters, R. (2007). De toekomst van flexibele arbeid: hoe flexibel is Nederland? Hoofddorp: TNO.

Leede, J. de \& Goudswaard, A. (2008). Flexibele organisatie: Nieuwe inzichten over de afstemming tussen strategie, personeel en proces. In: S. Dhondt \& F. Vaas (red.). Waardevol werk: Van arbeidskwaliteit naar sociale innovatie. Den Haag: Lemma, 216-230.

Leede, J. de, Cox-Woudstra, E., Goudswaard, A., Rhijn, G. van, Schie, J. van, Tuinzaad, B. \& Veldhuisen, A. van (2002). Flexibele inzet van personeel in productiebedrijven. Praktijkvoorbeelden, trends, effecten, instrumenten. Hoofddorp: TNO Arbeid/TNO Industrie.

Pedersen, H.S., Hansen, C.B. \& Mahler, S. (2007). Temporary agency work in the European Union. Dublin: European Foundation for the Improvement of Living and Working Conditions (only available in electronic format).

Storrie, D. (2002). Temporary agency work in the European Union. Dublin: European Foundation for the Improvement of Living and Working Conditions. 